\title{
Radiographic analysis to assess the seed structure of Crotalaria juncea L. ${ }^{1}$
}

\author{
Natália Arruda $^{2 *}$, Silvio Moure Cicero², Francisco Guilhien Gomes-Junior ${ }^{2}$
}

\begin{abstract}
The X-ray test is a simple, fast, non-destructive, and highly precise test that enables detailed examination of internal seed morphology and identification of seed damage and its location and type. The objective of the present study was to evaluate the efficiency of the X-ray test and the relationship between the structure of Crotalaria juncea seeds and germination. Six lots of Crotalaria juncea seeds of the IAC-KR1 cultivar were subjected to X-ray and germination tests. Normal and abnormal seedlings and dead seeds were photographed and analyzed together with the X-ray images of the seeds. Results showed that analysis of X-ray images is effective in identifying mechanical damage, stink bug damage, and deteriorated tissues in Crotalaria juncea seeds and is able to establish an association between their occurrence and germination.
\end{abstract}

Index terms: image analysis, germination, internal morphology.

\section{Análise radiográfica para avaliação da estrutura de sementes de Crotalaria juncea L.}

\begin{abstract}
RESUMO - O teste de raios X é um teste rápido, simples, não destrutivo e de alta precisão, que possibilita examinar com detalhes, a morfologia interna da semente, identificar áreas danificadas, sua localização e tipos de danos. O objetivo na presente pesquisa foi avaliar a eficiência do teste de raios X e relacionar a estrutura de sementes de Crotalaria juncea com a germinação. Foram utilizados seis lotes de sementes de Crotalaria juncea, cultivar IAC-KR1. As sementes foram submetidas aos testes de raios X e germinação. As plântulas normais, anormais e sementes mortas foram fotografadas e analisadas paralelamente às imagens radiográficas das sementes. Verificou-se que análise de imagens radiográficas possibilita a identificação de danos mecânicos, danos por percevejos e tecidos deteriorados em sementes de Crotalaria juncea, com efeitos negativos à germinação.
\end{abstract}

Termos para indexação: análise de imagens, germinação, morfologia interna.

\section{Introduction}

Successful establishment of economically important field crops requires the use of high quality seeds. Fast and simple techniques that provide accurate information in regard to seed quality can contribute to selection of seed lots in quality control programs and, consequently, increase the efficiency of the production system.

The seed of sunn hemp (Crotalaria juncea L.), like the soybean seed, is very sensitive to mechanical damage since vital parts of the embryonic axis are located under a thin seed coat that offers practically no protection (França-Neto and Henning, 1984). Thus, mechanical injury, caused during seed harvest and processing is one of the main causes of reduction in its quality (Paiva et al., 2000), and may lead to rejection of seed lots.

Among the resources available for seed analysis, the use of X-ray test, a technique recommended by the International Seed Testing Association - ISTA (2004) and by the Rules for Seed Testing (Brasil, 2009), is highly worthwhile for various kinds of seeds since it is a fast and non-destructive test basically for the purpose of detecting morphological and structural abnormalities of the seed and identifying their causes.

The principle of the technique is based on differential absorption of X-rays by seed tissues, depending on the thickness, density, and composition of these tissues, in addition to the wavelength of the radiation (ISTA, 2004). Seeds are placed between a low energy source of X-rays

\footnotetext{
${ }^{1}$ Submitted on 10/02/2015. Accepted for publication on 02/11/2016.

${ }^{2}$ Departamento de Produção Vegetal, USP/ESALQ, Caixa Postal 9, 13418-900, Piracicaba, SP, Brasil.

*Corresponding author $<$ nathy.a@hotmail.com $>$
} 
and a photosensitive film. When the X-rays cross through the seed and reach the film, a latent image is created. After the film is processed, an image of light and dark shadows is formed, a permanent image on the X-ray film. Darker areas of the X-ray correspond to the parts in which the X-rays penetrate more easily, whereas lighter areas represent denser parts of the seed (Simak, 1991). This same reasoning applies to interpretation of images obtained by digital X-ray equipment (without use of film), with the advantage of greater speed in acquiring images and better quality (contrast and resolution).

The X-ray test has been used in seed studies since the 1950s, when Simak and Gustafsson (1953) showed its viability for evaluation of the quality of Pinus sylvestris $\mathrm{L}$ seeds. Thus, this technique has been used in genetic plant breeding studies, enabling detection of abnormalities in embryos and determination of their stage of development, as well as in isolation of mutant embryos of Arabidopsis haliana (Bino et al., 1993). It also allowed seed morphology to be related to germination or morphology of seedlings of diverse agricultural and forest species (Burg et al., 1994; Battisti et al., 2000; Machado and Cicero, 2003; Oliveira et al., 2003; Mondo and Cicero, 2005; Pupim et al., 2008; Pinto et al., 2009a; Carvalho et al., 2010; Gagliardi and Marcos-Filho, 2011; Kobori et al., 2012; Silva, P.P. et al., 2014; Gomes et al., 2014; Silva, V.N. et al., 2014).

The X-ray test has also been effective in identifying injuries from "moisture" in soybean seeds (Obando-Flor et al., 2004; Forti et al., 2010) and from stink bugs in soybean (Obando-Flor et al., 2004; Pinto et al., 2009b) and in common bean (Forti et al., 2008) seeds, evaluation of fissures in rice seeds (Menezes et al., 2012), and mechanical injuries in maize seeds (Carvalho et al., 1999; Cicero and Banzatto-Junior, 2003; Gomes-Junior and Cicero, 2012).

The X-ray test has been considered effective for evaluating mechanical damage in seeds because seeds can be examined individually in expanded images, which will be able to indicate seed damage and its extent and location in a detailed manner. In addition, the low radiation doses absorbed during the X-ray test does not cause genetic mutations in the seed and does not affect its germination (Bino et al., 1993). Thus, the seed subjected to analysis can be germinated, which allows a relation to be established between the occurrence of injuries and the damage caused to germination.

Therefore, the objective of this study was to evaluate the effectiveness of the X-ray test in relating seed structure of Crotalaria juncea to germination.

\section{Material and Methods}

The study was conducted at the Image Analysis and Seed Analysis Laboratories of the Crop Science Department (LPV), College of Agriculture "Luiz de Queiroz" (ESALQ), University of São Paulo (USP), in Piracicaba, SP, Brazil. Six seed lots of sunn hemp (Crotalaria juncea L.), cultivar IAC-KR1, were used, and the following evaluations were carried out:

Water content was determined before setting up the X-ray and germination tests by the laboratory oven method at $105^{\circ} \mathrm{C}$ $( \pm 3)$ for 24 hours (Brasil, 2009) in two $5 \mathrm{~g}$ samples. The results were expressed in mean percentage (wet basis) per lot.

$X$-ray testing was carried out with eight replications of 25 seeds per lot. Seeds were placed on a sheet of transparent acetate with dimensions of $210 \times 297 \mathrm{~mm}$ using a doublesided adhesive tape to fasten the seeds in an appropriate position (all the seeds were placed with the embryonic axis turned upward). The seeds were numbered according to the position occupied on the acetate sheet so that they could be identified in later evaluations. After that, the acetate sheet with the seeds was placed in a digital X-ray device, Faxitron ${ }^{\circledR}$ model MX-20 DC-12, with automatic adjustment of exposure time and intensity of X-rays, connected to a Core 2 Duo computer (3.16 GHz, 2 GB of RAM memory, Hard Disk of $160 \mathrm{~GB}$ ) and MultiSyne ${ }^{\circledR}$ monitor (LCD 1990SX, 17 inch) at a distance of $19.1 \mathrm{~cm}$ from the source of radiation emission. The images generated were saved on the computer hard disk for later analysis. The seeds that had already been X-rayed were removed from the acetate sheet and transferred to a plastic tray with individual cells, numbering them in the same order they were on the acetate sheet. After that, the seeds were subjected to the germination test.

The germination test was carried out on paper towel moistened with water at a proportion (weight : weight) of 1:2.5 (paper and water). The seeds, previously numbered (identified), were distributed on two sheets of paper towel (on the upper third of the substrate, to allow seedling development in an individualized manner), covered with another sheet. The rolls were placed in a seed germinator at $20-30{ }^{\circ} \mathrm{C}$, and evaluation was carried out on the fourth day after sowing in germination first count, according to the criteria established by the Rules for Seed Testing (Brasil, 2009). After that, normal seedlings (whose seeds exhibited some type of damage), abnormal seedlings, and dead seeds were photographed by a Nikon ${ }^{\circledR}$ D1 digital camera, and the images were saved on the computer hard disk for later analysis.

Mechanical damage, damage caused by stink bugs, and the presence of deteriorated tissues observed in X-ray analysis of the seeds, received scores according to the criteria shown 
in Table 1, following the classification proposed by Cicero et al. (1998) for maize seeds and adapted for Crotalaria juncea L. seeds. Thus, the following scores were attributed: 1.1, 1.2, $1.3,2.1,2.2,2.3,3.1,3.2$, and 3.3, with the first and the second number of each notation corresponding to the embryonic axis and to the cotyledons, respectively. The results arising from image analysis were not analyzed statistically. The number of seeds classified within each score and the total of normal and abnormal seedlings and dead seeds were calculated in percentages. The interpretation of the X-ray results was compared to the photographic images of the seedlings or dead seeds coming from the germination test.

Table 1. Criteria for scoring mechanical damage, stink bug damage, and deteriorated tissues observed in the embryonic axis and in the cotyledons of Crotalaria juncea seeds of the cv. IAC-KR1, evaluated by the X-ray test.

\begin{tabular}{|c|c|c|}
\hline Score & Embryonic axis & Cotyledons \\
\hline 1 & $\begin{array}{l}\text { Absence of mechanical damage, stink bug damage, and deteriorated } \\
\text { tissues. }\end{array}$ & $\begin{array}{l}\text { Absence of mechanical damage, stink bug damage, and } \\
\text { deteriorated tissues. }\end{array}$ \\
\hline 2 & $\begin{array}{l}\text { Absence of mechanical damage; however, there is subtle stink bug } \\
\text { damage and deteriorated tissues to a lower extent in vital parts } \\
\text { (damage not severe). }\end{array}$ & $\begin{array}{l}\text { Mechanical damage to a small extent, without loss of part of } \\
\text { the cotyledons, stink bug damage, and deteriorated tissues } \\
\text { of small extent (damage not severe). }\end{array}$ \\
\hline 3 & $\begin{array}{l}\text { Mechanical damage of greater extent that leads to sectioning and } \\
\text { loss of the embryonic axis, stink bug damage, and deteriorated } \\
\text { tissues to a greater extent in vital parts (severe damage). }\end{array}$ & $\begin{array}{l}\text { Mechanical damage to a greater extent, resulting in loss of } \\
\text { part of the cotyledons, stink bug damage, and deteriorated } \\
\text { tissues to a greater extent (severe damage). }\end{array}$ \\
\hline
\end{tabular}

\section{Results and Discussion}

The water content of Crotalaria juncea seeds ranged from $8.2 \%$ to $9.1 \%$. According to Simak (1991), seed water content influences optical density, that is, the lower the water content is, the greater the optical density, which allows greater differentiation of internal parts of the seeds viewed in the X-ray images. However, for Gagliardi and MarcosFilho (2011), the X-ray test with relatively dry bell pepper seeds ( $6 \%$ water content) in most cases did not allow clear visualization of the component parts of the seeds, which was possible when they had $12 \%$ water content.

For sunn hemp seeds, these water contents $(8.2 \%$ to $9.1 \%)$ did not create difficulty in visualization of the embryonic axis and of the cotyledons. In studies carried out with analysis of X-rays in soybean (Pinto et al., 2007) and common bean (Forti et al., 2008) seeds, it was also possible to view the seed structure with water content greater than $9 \%$. It is important to note that each species has its own characteristics of density and chemical composition, factors that significantly affect visualization of the X-rayed parts of the seeds.

In analysis of the X-ray images, a low percentage of malformed seeds was observed. Because of this low value and since they did not exhibit other damage, these seeds received scores according to the location of the malformation (embryonic axis or cotyledons). Therefore, these seeds were included in scores 1.2, 1.3, or 3.1, giving rise to normal seedlings (1.2) or abnormal seedlings $(1.3,3.1)$ (Table 2).

The results of the X-ray test for the six lots of Crotalaria juncea of the cultivar IAC-KR1 can be observed in Table 2 .
According to analysis of seed structure, it can be seen that the sunn hemp seeds exhibited various kinds of damage; among them are mechanical damage, stink bug damage, and damage associated with deteriorated tissues, which led to losses in seed germination since the damages considered as severe resulted in abnormal seedlings or in dead seeds.

Seeds that were classified with scores 1.1 (absence of damage) and 1.2 (cotyledon damage not severe) gave rise to more than $60 \%$ normal seedlings; this was observed for seed lots 1, 3, and 4; and lot 1 stood out with $77 \%$ normal seedlings (scores 1.1 and 1.2) (Table 2).

Seeds with absence of damage (score 1.1), in addition to giving rise to normal seedlings, gave rise to abnormal seedlings or seedlings that did not germinate. Lots 2 and 3 exhibited the highest percentages, $8 \%$ and $10 \%$, respectively, of abnormal seedlings; lot 6 had the highest percentage ( $2 \%$ ) of dead seeds (Figure 1). According to Burg et al. (1994), some seeds that had a normal appearance in the X-ray test may have problems in germination, possibly due to infections by microorganisms or from being physiologically compromised.

According to the percentage of normal seedlings (Table 2), that is, seeds classified with scores 1.1, 1.2, 2.1, and 2.2, it can be observed that lot 1 performed best, whereas lots 5 and 6 had the worst performances.

The lots had low incidence of damage considered as not severe (scores 2.1 and 2.2). These damages, most of the time, were associated with deteriorated tissues, giving rise to normal seedlings. When the damage that was not severe occurred in the embryonic axis along with severe damage in the cotyledons (score 2.3), abnormal seedlings arose or 
the seeds did not germinate. In this case, there was damage through deterioration of the tissues (embryonic axis or more than $50 \%$ of the cotyledons) and mechanical damage or damage from stink bugs (cotyledons).

Table 2. Percentage of Crotalaria juncea seeds of cv. IAC-KR1, evaluated by the X-ray test, that received scores based on the presence of absence of mechanical damage, stink bug damage, and deteriorated tissues that resulted in normal seedlings (NS), abnormal seedlings (AS), dead seeds (DS), and hard seeds (HS) in the germination first count test.

\begin{tabular}{|c|c|c|c|c|c|c|c|c|c|c|c|c|}
\hline \multirow{2}{*}{ Score $^{1}$} & \multicolumn{4}{|c|}{ Lot 1} & \multicolumn{4}{|c|}{ Lot 2} & \multicolumn{4}{|c|}{ Lot 3} \\
\hline & NS & AS & DS & HS & NS & AS & DS & $\mathrm{HS}$ & NS & AS & DS & HS \\
\hline 1.1 & 73.0 & 4.5 & - & 1.5 & 56.5 & 8.0 & - & 1.0 & 59.5 & 10.0 & - & - \\
\hline 1.2 & 4.0 & - & - & - & 3.0 & - & - & - & 4.0 & - & - & - \\
\hline 1.3 & - & 1.5 & - & - & - & 0.5 & - & - & - & 0.5 & - & - \\
\hline 2.1 & 0.5 & - & - & - & 0.5 & - & - & - & 1.5 & - & - & - \\
\hline 2.2 & 1.0 & - & - & - & 0.5 & - & - & - & 2.5 & - & - & - \\
\hline 2.3 & - & - & 0.5 & - & 0.5 & 2.0 & 1.0 & - & - & 3.5 & - & - \\
\hline 3.1 & - & 7.5 & 0.5 & - & - & 6.0 & 0.5 & - & - & 7.5 & - & - \\
\hline 3.2 & - & 0.5 & - & - & - & 3.5 & 1.0 & - & - & 2.0 & - & - \\
\hline 3.3 & - & 4.5 & 0.5 & - & - & 13.0 & 2.5 & - & - & 7.0 & 2.0 & - \\
\hline $\mathrm{T}^{2}$ & 78.5 & 18.5 & 1.5 & 1.5 & 61.0 & 33.0 & 5.0 & 1.0 & 67.5 & 30.5 & 2.0 & - \\
\hline \multirow{2}{*}{ Score $^{1}$} & \multicolumn{4}{|c|}{ Lot 4} & \multicolumn{4}{|c|}{ Lot 5} & \multicolumn{4}{|c|}{ Lot 6} \\
\hline & NS & AS & DS & HS & NS & AS & DS & HS & NS & AS & DS & HS \\
\hline 1.1 & 60.5 & 5.5 & 0.5 & 0.5 & 49.5 & 6.5 & 0.5 & - & 51.0 & 5.5 & 2.0 & - \\
\hline 1.2 & 7.0 & - & - & - & 7.5 & - & - & - & 5.5 & - & - & - \\
\hline 1.3 & - & 2.0 & - & - & - & 2.0 & - & - & - & 0.5 & - & - \\
\hline 2.1 & 2.0 & - & - & - & 1.5 & - & - & - & 2.5 & - & - & - \\
\hline 2.2 & 1.0 & - & - & - & 1.0 & - & - & - & - & - & - & - \\
\hline 2.3 & - & 1.5 & - & - & - & 2.5 & 0.5 & - & - & 2.0 & 0.5 & - \\
\hline 3.1 & - & 9.0 & 1.0 & - & - & 10.5 & 1.0 & - & - & 13.0 & 5.0 & - \\
\hline 3.2 & - & 2.0 & 1.0 & - & - & 2.5 & 0.5 & - & - & 1.5 & 0.5 & - \\
\hline 3.3 & - & 5.5 & 1.0 & - & - & 11.0 & 3.0 & - & - & 5.5 & 5.0 & - \\
\hline $\mathrm{T}^{2}$ & 70.5 & 25.5 & 3.5 & 0.5 & 59.5 & 35.5 & 5.5 & - & 59.0 & 28.0 & 13.0 & - \\
\hline
\end{tabular}

${ }^{1}$ The first number refers to the embryonic axis and the second, to the cotyledons. The scores 1,2 , and 3 correspond to the absence of damage, non-severe damage, and severe damage, respectively.

${ }^{2}$ Total of normal seedlings (NS), abnormal seedlings (AS), dead seeds (DS), and hard seeds (HS).
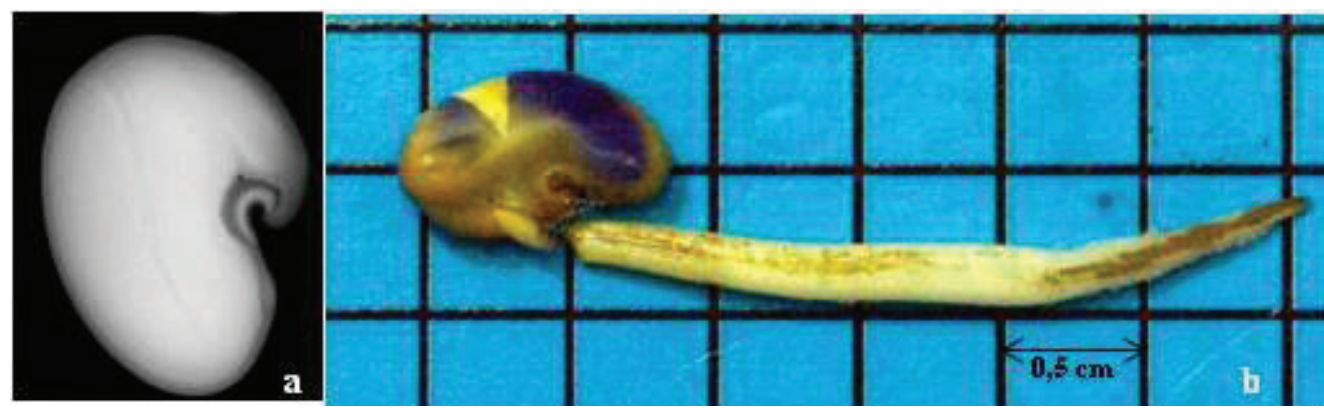

Figure 1. X-ray image of Crotalaria juncea seed of cv. IAC-KR1, with absence of damage in seed parts (a), giving rise to an abnormal seedling (b).

From Table 2, it was observed that in all the lots, the occurrence of abnormal seedlings and dead seeds were more evident when the damage (mechanical, from stink bugs, and deteriorated seed tissue) was located in the embryonic axis (score 3.1, 3.2, and 3.3). As can be observed, lot 6 exhibited the highest percentage of abnormal seedlings and dead seeds, with score 3.1 ( $13 \%$ and 5\%, respectively), and lot 2, with $13 \%$ of abnormal seedlings coming from seeds, with score 3.3. 
Table 3 contains the descriptions of the main types of damage observed from a total of 1200 seeds evaluated, involving the six seed lots. Seeds that received score 3.2 from the X-ray test can be characterized by cracks or fissures, deteriorated tissues, or stink bug damage in the embryonic axis. For damage in cotyledons to be considered non-severe, it can be characterized by deteriorated tissues, fissures or cracks, or stink bug damage; however, this damage must be far from the embryonic axis and less than 50\% (visual analysis) of the cotyledons. In some cases, there may be two or more types of damage in a single seed.

Table 3. Description and percentage of occurrence of the main types of damage observed in Crotalaria juncea seeds of the cv. IAC-KR1, evaluated by the X-ray test.

\begin{tabular}{lcc}
\hline \multicolumn{1}{c}{ Description of damage } & Occurrence $^{1}$ & Examples $^{-}$ \\
\hline Cracks or fissures in the cotyledons, without arriving at the embryonic axis (scores 1.2 and 1.3) & $1.92 \%$ & - \\
Cracks or fissures in diverse parts of the seed (scores 2.3, 3.1, 3.2, and 3.3) & $0.67 \%$ & Figure 2 a, c \\
Stink bug damage in the cotyledons, without arriving at the embryonic axis (scores 1.2 and 1.3) & $3.58 \%$ & Figure 4 a \\
Stink bug damage and fissures in the embryonic axis and in the cotyledons (scores 2.2, 2.3, 3.1, & $3.33 \%$ & - \\
3.2, and 3.3) & $4.17 \%$ & Figure 3 a \\
Deteriorated tissues in the cotyledons, without arriving at the embryonic axis (scores 1.2 and 1.3) & \\
Deteriorated tissues in various parts of the seed (scores 2.3, 3.2, and 3.3) &
\end{tabular}

${ }^{1}$ Percentage in relation to the total of 1200 seeds evaluated by the X-ray test.

Among the analyzed seeds, those that received a score of severe damage in the embryonic axis and in the cotyledons $(2.3,3.1,3.2$, and 3.3), represented by cracks and fissures in various parts of the seed, had the highest occurrence, at $16.67 \%$ (Table 3). In contrast, seeds with stink bug damage in the cotyledons, without arriving at the embryonic axis (scores 1.2 and 1.3), had the lowest occurrences, at $0.67 \%$.

In Figures 2a and 2c, severe damages are observed caused by cracks or fissures in various parts of the seed, resulting in dead seeds (Figures 2. b and 2. d). It is important to highlight that this was the most frequent type of damage in the seeds under study. Sunn hemp seeds are very sensitive to mechanical damage since the vital parts of the embryonic axis (radicle, hypocotyl, and plumule) lie under a thin seed coat, which offers practically no protection.

The main source of mechanical injury is the harvest operation (França-Neto and Henning, 1984). According to Calegari et al. (1993), harvest is one of the main limiting factors for production of sunn hemp seeds, due to uneven maturation; there is a great deal of loss at harvest through pod dehiscence or through immediate or latent mechanical damage. Another important observation is that some seeds, in addition to mechanical damage (cracks or fissures), also had dark stains, associated with deteriorated tissues, indicated with an arrow in Figure 2c.

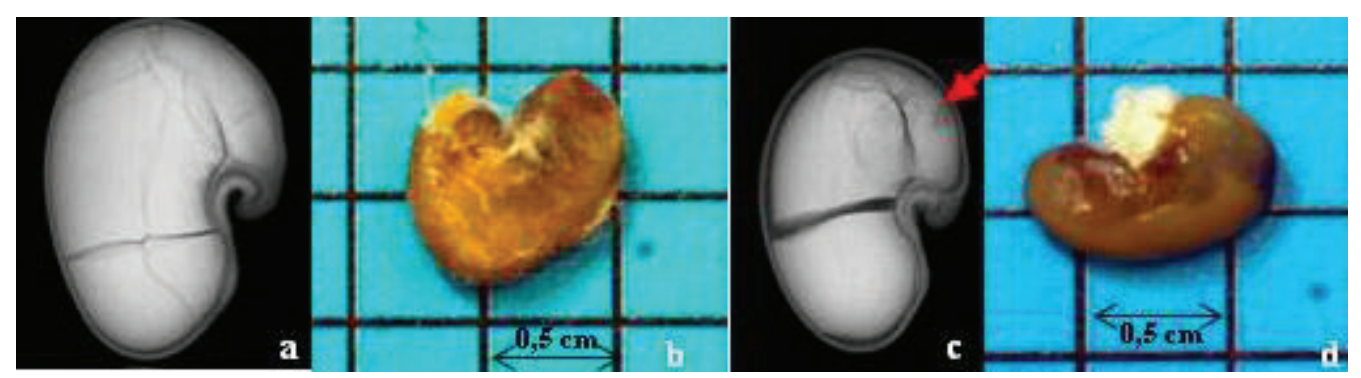

Figure 2. X-ray images of Crotalaria juncea seeds of cv. IAC-KR1 (a, c), showing mechanical damage in the embryonic axis and in the cotyledons (score 3.3), resulting in dead seeds (b, d).

Using image analysis to identify the effects of mechanical damage, moisture damage, or damage from stink bug on germination of soybean seeds, Obando-Flor et al. (2004) concluded that this analysis was an effective alternative in relation to other methods for the same purpose and had the added advantage of being a non-destructive method. Cicero et al. (1998), analyzing mechanical damage in maize seeds related to germination, found that ruptures present in the endosperm, causing restrictions in nutrients translocation to the embryonic axis, or those that occurred directly in the 
embryonic axis had a negative effect on seed germination.

In Table 3, it can be observed that $4.17 \%$ of the seeds exhibit severe damage brought about by deterioration of tissues in various parts of the seed (Figure 3 a). Most of the time, the result was abnormal seedlings or dead seeds. Seeds with severe damage in the cotyledons (more than $50 \%$ deteriorated tissues or damage near the embryonic axis) and in the embryonic axis generally resulted in abnormal seedlings or dead seeds, especially when the damage was in the embryonic axis. This was also observed by Mondo and Cicero (2005) in maize seeds and in common bean seeds (Forti et al., 2008).

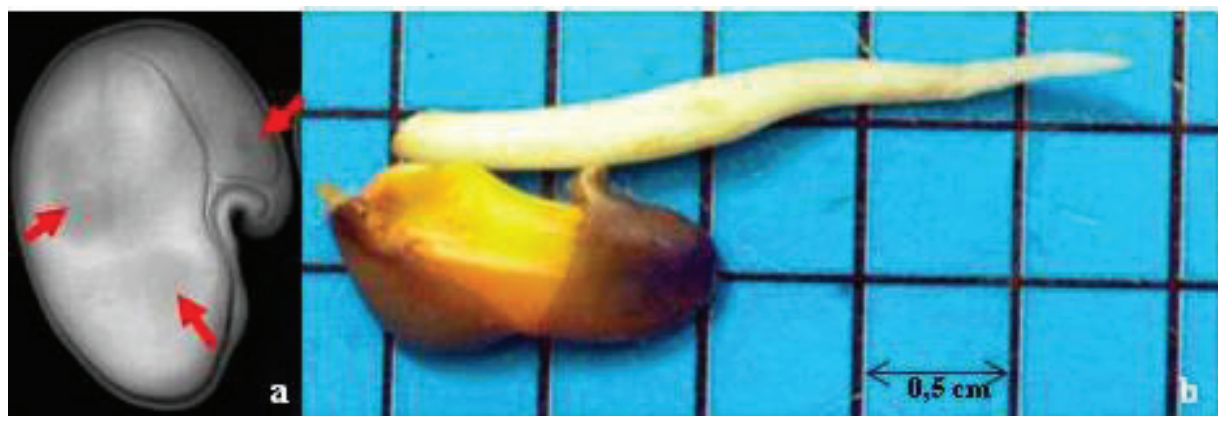

Figure 3. X-ray image of Crotalaria juncea seed of cv. IAC-KR1 (a), showing deteriorated tissue in the embryonic axis and in the cotyledons (score 3.3), giving rise to abnormal seedling (b).

In Figure 4 a, stink bug damage and fissures in the embryonic axis and in cotyledons are observed (scores 2.3, $3.1,3.2$, and 3.3 ), representing $3.58 \%$ of the total number of analyzed seeds, resulting in abnormal seedlings (Figure $4 \mathrm{~b}$ ) or dead seeds. From analysis of X-ray images, it could be observed that the seeds that exhibited stink bug damage in the embryonic axis generally proved to be dead seeds. According to França-Neto et al. (1998), the damage brought about by perforation from stink bug, depending on the location and extent of the damaged area, as, for example, the embryonic axis, makes the seed incapable of germinating because that region is vital in metabolic processes since the parts of the embryo (plumule, hypocotyl, and radicle) that will give rise to the future seedling develop there.

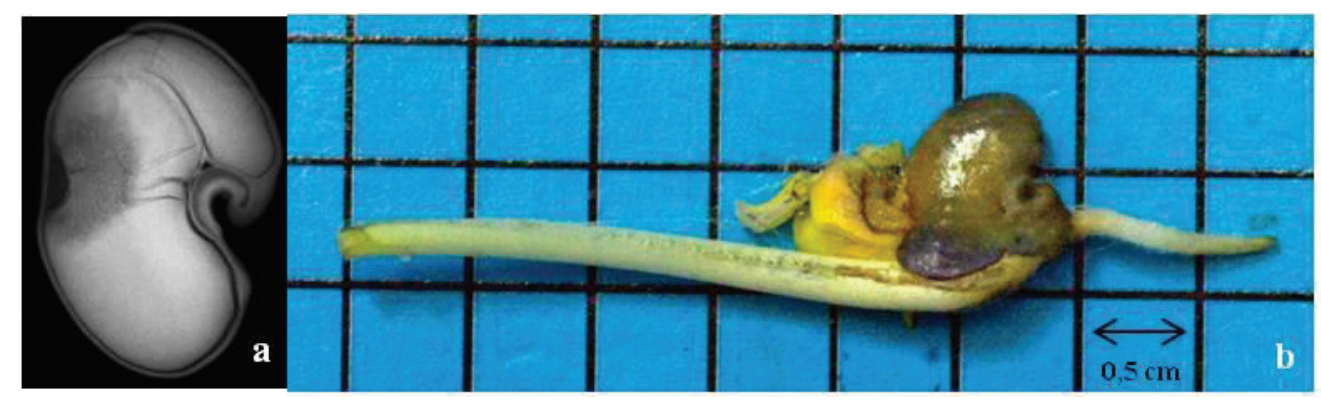

Figure 4. X-ray image of Crotalaria juncea seed of cv. IAC-KR1 (a), showing mechanical damage in the embryonic axis, mechanical damage, and stink bug damage in the cotyledons (score 3.3), giving rise to abnormal seedling (b).

The X-ray test proved to be effective in evaluation of the structure of sunn hemp seeds, and it could be observed that the presence of mechanical damage, stink bug damage, or deteriorated tissues considered to be severe in the region of the embryonic axis and in the cotyledons resulted in abnormal seedlings or in dead seeds. In contrast, it was evident that these occurrences classified as not very severe in the cotyledons generally did not impair germination.

\section{Conclusions}

Analysis of X-ray images enables identification of mechanical damage, stink bug damage, and damage associated with tissue deterioration in Crotalaria juncea seeds that have negative effects on germination. 


\section{Acknowledgments}

Our thanks to the Conselho Nacional de Desenvolvimento Científico e Tecnológico (CNPq) for granting a scholarship to the first author, and to the Piraí Sementes company for providing seeds.

\section{References}

BATTISTI, A.; CANTINI, R.; FECI, E.; FRIGIMELICA, G.; GUIDO, M.; ROQUES, A. Detection and evaluation of seed damage of cypress, Cupressus semprevirens L. Seed Science and Technology, v.28, n. 3, p. 729-738, 2000.

BINO, R.J.; AARTSE, J.W.; BURG, W.J. van der. Non destructive $\mathrm{X}$-ray analysis of Arabidopsis embryo mutants. Seed Science Research, v.3, p.167-170, 1993. http://journals.cambridge.org/action/ displayAbstract? fromPage $=$ online $\&$ aid $=1353120$

BRASIL. Ministério da Agricultura, Pecuária e Abastecimento. Regras para análise de sementes. Ministério da Agricultura, Pecuária e Abastecimento. Secretaria de Defesa Agropecuária. Brasília: MAPA/ACS, 2009, 395p. http:// www.agricultura.gov.br/arq_editor/file/2946_regras_analise_sementes.pdf

BURG, W.J. van der; AARTSE, J.W.; ZWOL, R.A. van; JALINK, H.; BINO, R.J. Predicting tomato seedling morphology by X-ray analysis of seeds. Journal American Society for Horticultural Science, v.119, n.2, p. 258-263, 1994. http://journal.ashspublications.org/content/119/2/258.abstract

CALEGARI, A; ALCÂNTARA, P.B.; MIYASAKA, S; AMADO, T.J.C. Caracterização das principais espécies de adubos verde. In: COSTA, M.B.B. (Coord.). Adubação verde no sul do Brasil, p. 206-319, 1993.

CARVALHO, M.L.M.; ALVES, R.A.; OLIVEIRA, L.M. Radiographic analysis in castor bean seeds (Ricinus communis L.). Revista Brasileira de Sementes, v.32, n.1, p.170-175, 2010. http://www.scielo.br/scielo. php?pid=S0101-31222010000100019

CARVALHO, M.L.M.; VAN AELST, A.C.; VAN ECK, J.W.; HOEKSTRA, F.A. Pre-harvest stress cracks in maize (Zea mays L.) kernels as characterized by visual, X-ray and low temperature scanning electron microscopical analysis: effect on kernel quality. Seed Science Research, v.9, n.3, p.227-236, 1999. https://www. researchgate.net/publication/40193333_Preharvest_stress_cracks_in_maize Zea_mays_L_kernels_as_characterized_by_visual_Xray_and_low_temperature scanning_electron_microscopical_analysis_effect_on_kernel_quality

CICERO, S.M.; BANZATTO-JUNIOR, H.L. Avaliação do relacionamento entre danos mecânicos e vigor, em sementes de milho, por meio da análise de imagens. Revista Brasileira de Sementes, v.25, n.1, p. 29-36, 2003. http:// www.scielo.br/pdf/rbs/v25n1/19627.pdf

CICERO, S.M.; HEIJDEN, G.W.A.M.; BURG W.J. van der, BINO, R.J. Evaluation of mechanical damages in seeds of maize (Zea mays L). by X-ray and digital imaging. Seed Science and Technology, v.26, n.2, p.603-612, 1998.

FORTI, V.A.; CICERO, S.M.; PINTO, T.L.F. Análise de imagens na avaliação de danos mecânicos e causados por percevejos em sementes de feijão. Revista Brasileira de Sementes, v.30, n.1, p.121-130, 2008. http://www.scielo.br/ scielo.php?script=sci_arttext\&pid=S0101-31222008000100016

FORTI, V.A.; CICERO, S.M.; PINTO, T.L.F. Avaliação da evolução de danos por "umidade" e redução do vigor em sementes de soja, cultivar TMG113-RR, durante o armazenamento, utilizando imagens de raios-X e testes de potencial fisiológico. Revista Brasileira de Sementes, v.32, n.3, p.123-133, 2010. http:// www.scielo.br/scielo.php?pid=S0101-31222010000300014\&script=sci_arttext
FRANÇA-NETO, J.B.; HENNING, A.A. Qualidade fisiológica e sanitária de sementes de soja. Londrina: EMBRAPA - CNPSo, 39p.1984. (Circular Técnica, 9)

FRANÇA-NETO, J.B.; KRYZANOWSKI, F.C.; COSTA, N.P. O teste de tetrazólio em sementes de soja. Londrina: EMBRAPA-CNPSo, 72p. 1998. (EMBRAPA-CNPSo Documentos, 116).

GAGLIARDI, B.; MARCOS-FILHO, J. Relationship between germination and bell pepper seed structure assessed by the X-ray test. Scientia Agrícola, v.68, n.4, p.411-416, 2011. http://www.scielo.br/scielo.php?pid=S010390162011000400004\&script=sci_arttext

GOMES, K.B.P.; MARTINS, R.C.C.; MARTINS, I.S.; GOMES-JUNIOR, F.G. Avaliação da morfologia interna de sementes de Terminalia argentea (Combretaceae) pelo teste de raios X. Revista Ciência Agronômica, v. 45, n.4, p. 752-759, 2014. http://www.scielo.br/pdf/rca/v45n4/13.pdf

GOMES-JUNIOR, F.G.; CICERO, S.M. X-Ray analysis to assess mechanical damage in sweet corn seeds. Revista Brasileira de Sementes, v.34, n.1 p.78-85, 2012. http://www.scielo.br/scielo.php?pid=S010131222012000100010\&script $=$ sci_arttext

ISTA. International Rules for Seed Testing Association, 174p. 2004.

KOBORI, N.N.; CICERO, S.M.; MEDINA, P.F. Teste de raios X na avaliação da qualidade de sementes de mamona. Revista Brasileira de Sementes, v.34, n.1 p.125-133, 2012. http://www.scielo.br/scielo.php?pid=S010131222012000100016\&script=sci_arttext

MACHADO, C.F.; CICERO, S.M. "Aroeira-branca" [Lithraea molleoides (Vell.) Engl. -Anacardiaceae] seed quality evaluation by the X-ray test. Scientia Agricola, v.60, n.2, p.393-397, 2003. http://www.revistas.usp.br/sa/ article/view/21860/23884

MENEZES, N.L.; CICERO, S.M.; VILLELA, F.A.; BORTOLOTTO, R.P. Using X-Rays to evaluate fissures in rice seeds dried artificially. Revista Brasileira de Sementes, v.34, n.1, p.70-77, 2012. http://www.scielo.br/scielo. php?pid=S0101-31222012000100009\&script $=$ sci_abstract

MONDO, V.H.V.; CICERO, S.M. Análise de imagens na avaliação da qualidade de sementes de milho localizadas em diferentes posições na espiga. Revista Brasileira de Sementes, Pelotas, v.27, n.1, p. 9-18, 2005. http://www. scielo.br/scielo.php?pid=S0101-31222005000100002\&script=sci arttext

OBANDO-FLOR, E.P.; CICERO, S.M.; FRANÇA-NETO, J.B.; KRZYZANOWSKI, F.C. Avaliação de danos mecânicos em sementes de soja por meio da análise de imagens. Revista Brasileira de Sementes, v.26, n.1, p.68-76, 2004. http://www.scielo.br/scielo.php?script=sci arttext\&pid=S0101-31222004000100011

OLIVEIRA, L.M.; CARVALHO, M.L.M.; DAVIDE, A.C. Utilização do teste de raios X na avaliação da qualidade de sementes de canafístula (Peltophorum dubium (sprengel) Taubert.). Revista Brasileira de Sementes, v.25, n.1, p.116 - 120, 2003. http://www.scielo.br/scielo.php?script=sci arttext\&pid=S0101$31222003000100018 \&$ Ing $=$ pt\&nrm $=$ iso

PAIVA, L.E.; MEDEIROS, S.F.; FRAGA, A.C. Beneficiamento de sementes de milho colhidas mecanicamente em espigas: efeitos sobre danos mecânicos e qualidade fisiológica. Ciência Agrotécnica, v.24, p. 846-856, 2000. http:// www.editora.ufla.br/_adm/upload/revista/24-4-2000_03.pdf

PINTO, T.L.F.; MARCOS-FILHO, J.; FORTI, V.A.; CARVALHO, C.; GOMES-JUNIOR, F.G. Avaliação da viabilidade de sementes de pinhão manso pelos testes de tetrazólio e de raios X. Revista Brasileira de Sementes, v. 31, n. 2, p.195-2001, 2009a. http://www.scielo.br/scielo.php?pid=S0101$31222009000200023 \&$ script $=$ sci_arttext 
PINTO, T.L.F.; CICERO, S.M.; FRANÇA-NETO, J.B.; FORTI, V.A. An assessment of mechanical and stink bug damage in soybean seed using X-ray analysis test. Seed Science and Technology, v.37, n.1, p.110-120, 2009b. http://www.ingentaconnect.com/content/ista/sst/2009/00000037/00000001/ $\operatorname{art} 00013$

PINTO, T.L.F.; CICERO, S.M.; FORTI, V.A. Avaliação de danos por umidade, em sementes de soja, utilizando a técnica da análise de imagens. Revista Brasileira de Sementes, v.29, n.3, p.31-38, 2007. http://www.scielo.br/ scielo.php?script=sci_arttext\&pid=S0101-31222007000300004

PUPIM, T.L.; NOVEMBRE, A.D.L.C.; CARVALHO, M.L.M.; CICERO, S.M. Adequação do teste de raios X para avaliação da qualidade de sementes de embaúba (Cecropia pachystachya trec.). Revista Brasileira de Sementes, v. 30 , n. 2 , p. $28-32,2008$. http://www.scielo.br/scielo.php?script=sci arttext\&pid=S0101-31222008000200004

SIMAK, M. Testing of forest tree and shrub seeds by X-radiography. In: GORDON, A.G.; GOSLING, P.; WANG, B.S.P. (Ed.) Tree and Shrub Seed Handbook. Zurich: ISTA, 1991. p. 1-28.
SIMAK, M.; GUSTAFSSON, A. X-ray photography and sensitivity in forest tree species. Hereditas, v.39, n.3/4, p.458-468, 1953. http://onlinelibrary. wiley.com/doi/10.1111/j.1601-5223.1953.tb03430.x/pdf

SILVA, P.P.; FREITAS, R.A.; CÍCERO, S.M.; MARCOS-FILHO, J.; NASCIMENTO, W,M. Análise de imagens no estudo morfológico e fisiológico de sementes de abóbora. Horticultura Brasileira v. 32, p.210-214, 2014. http:// www.scielo.br/scielo.php?pid=S0102-05362014000200210\&script $=$ sci arttext

SILVA, V.N.; ARRUDA, N.; CICERO, S.M.; MAUS, C.A.; GIACOMELI, R. Morfologia interna e germinação de sementes de arroz de terras baixas produzidas em diferentes regimes hídricos. Irriga, v.19, n.3, p. 453-463, 2014. http://energia.fca.unesp.br/index.php/irriga/article/view/910 